\title{
Is There An Association Between Two-STAT4 Gene Polymorphisms and Rheumatoid Arthritis in Turkish Population?
}

\author{
Berrin YÜKSEL, ${ }^{1}$ Şebnem ATAMAN, ${ }^{2}$ Deniz EVCİK, ${ }^{3}$ Saime AY, ${ }^{4}$ Mine MUMCUOĞLU, ${ }^{1}$ Beyza ERDOĞAN ${ }^{5}$ \\ ${ }^{1}$ Department of Medical Genetics, Medical Faculty of Ufuk University, Ankara, Turkey \\ ${ }^{2}$ Division of Rheumatology, Department of Physical Medicine and Rehabilitation, Medical Faculty of Ankara University, Ankara, Turkey \\ ${ }^{3}$ Department of Therapy and Rehabilitation, Ankara University, Haymana Vocational School, Ankara, Turkey \\ ${ }^{4}$ Department of Physical Medicine and Rehabilitation, Medical Faculty of Ufuk University, Ankara, Turkey \\ ${ }^{5}$ Department of Biostatistics, Medical Faculty of Ankara University, Ankara, Turkey
}

\begin{abstract}
Objectives: The aim of this study was to investigate whether the rs7574865 and rs10181656 single nucleotide polymorphisms of the STAT4 gene confer susceptibility to rheumatoid arthritis (RA) in the Turkish population.

Patients and methods: Genomic DNA was obtained from 140 patients with RA and 138 ethnically matched healthy controls. Polymerase chain reaction-restriction fragment length polymorphism (PCR-RFLP) analysis was used to identify the rs7574865 and rs10181656 polymorphisms in the third intron of the STAT4 gene. The genotype distributions and allelic frequencies of these two polymorphisms were compared between RA patient group and controls. The relationship between the genotype distributions of the two single nucleotide polymorphisms and the clinical and laboratory data of RA patients was investigated.

Results: There were no significant differences between the groups regarding the allele frequencies of the rs 7574865 and rs 10181656 polymorphisms ( $p=0.654$ and $p=0.594$, respectively) and the genotype distributions of the two polymorphisms $(p=0.686$ and $p=0.467$, respectively). There was no correlation between the genotype distributions of the rs7574865 and rs10181656 polymorphisms of the STAT4 gene and the clinical features and laboratory findings of the RA patients.

Conclusion: Our study results indicated that the rs7574865 and rs10181656 polymorphisms in the STAT4 gene were not associated with a susceptibility to RA in the Turkish population.

Keywords: Gene polymorphism; rheumatoid arthritis; STAT4 gene.
\end{abstract}

Rheumatoid arthritis (RA, MIM 180300) is the most common chronic autoimmune disease. It affects $1 \%$ of the adult population worldwide and is associated with significant disability and early mortality. ${ }^{1}$ This disease has a complex mode of inheritance with suspected interrelated influences between environmental and genetic factors which are estimated to have a contribution rate of $50-60 \% .^{2}$ To date, the strongest genetic association with RA has been for certain alleles of human leukocyte antigen (HLA) class II molecules, which account for approximately onethird of the total genetic susceptibility. ${ }^{3}$ This leaves us with the fact that non-HLA susceptibility genes carry a larger load of the responsibility, but many of these still remain undiscovered. ${ }^{4}$ In recent years, it has been demonstrated that the association between the protein tyrosine phosphatase non-receptor 22 (PTPN22) gene and RA has the most significance outside of the HLA region in European and Asian populations. ${ }^{4-7}$

With the advent of genome-wide association studies, the difficulty of identifying new potential susceptibility loci has been resolved to some extent. ${ }^{8-10}$ However, a further step is needed to discriminate the false positives from the new putative susceptibility genes and identify the ones that are specific for

Received: July 26, 2013 Accepted: November 03, 2013

Correspondence: Berrin Yüksel, M.D. Ufuk Üniversitesi Tıp Fakültesi Tıbbi Genetik Anabilim Dalı, 06520 Balgat, Ankara, Turkey.

Tel: +90 312 - 2044257 e-mail: berrin.konuk@gmail.com

๑2014 Turkish League Against Rheumatism. All rights reserved. 
certain populations. In light of these efforts, an RA linkage peak in chromosome 2q was identified in families of European ancestry, and further investigations identified several polymorphic loci in the third intron of the signal transducer and activator of transcription 4 (STAT4) gene as the markers that had formed the subsequent peaks in earlier studies. ${ }^{11,12}$ The four single nucleotide polymorphisms (SNPs) in the third intron of the STAT4 gene (rs18889341, rs7574865, rs8179673, and rs10181656) were found to be in tight linkage disequilibrium, and they formed a susceptibility haplotype in various investigations that were replicated in European, North American, Colombian, Korean, Northwestern Chinese Han, Northern Chinese Han, Chinese, Egyptian, and Japanese populations. ${ }^{10,12-21}$ Among these four polymorphisms, rs7574865 had the most significant association with RA. ${ }^{10,12}$ However, there have been some conflicting results that reported no correlation between RA and STAT4, such as the studies that were conducted on the Southwestern Chinese Han population and on African Americans. ${ }^{10,22,23}$

The STAT4 gene encodes a transcription factor which can be phosphorylated for activation on either tyrosine or serine residues and is expressed in activated blood monocytes, macrophages, and dendritic cells at sites of inflamation in humans. ${ }^{24}$ It resides in the cytosol and transmits signals induced by the interleukin-12 (IL-12), IL-23, and IL-27 cytokines as well as type 1 interferons (IFNs). After being phosphorylated upon cytokine activation, it then translocates to the nucleus and plays a part in the differentiation and proliferation of IL-12-dependent $\mathrm{T}$ helper 1 (Th1) cells and IL-23-dependent Th17 cells and also has a role in monocyte activation and IFN production..$^{25}$ Knowing that Th- 1 and Th- 17 cells contribute significantly to chronic inflammatory diseases, STAT4 may have a crucial effect the pathogenesis of RA. ${ }^{26}$

The aim of this study was to investigate, to the best of our knowledge for the first time, whether the rs7574865 and rs10181656 SNPs confer susceptibility to RA in a Turkish populaton.

\section{PATIENTS AND METHODS}

\section{Participants}

After obtaining the participants' informed consent and receiving the approval of the Ethics Committee of Ankara Univerisity, 140 RA patients (120 females, 20 males) and 138 healthy controls (96 females, 42 males) were consecutively recruited from the outpatient clinic of the Division of Rheumatology, Department of Physical Medicine and Rehabilitation, Ankara University Medical School and the Department of Physical Medicine and Rehabilitation, Ufuk University Medical School, respectively. The characteristics of the RA patients and controls are presented in Table 1.

All patients included in the study fulfilled the American College of Rheumatology (ACR) 1987 revised criteria for $\mathrm{RA}^{27}$ and they were under a

Table 1. Characteristics of the patient and control groups

\begin{tabular}{|c|c|c|c|c|c|c|c|c|c|c|c|}
\hline \multirow[b]{2}{*}{ Characteristics } & \multicolumn{5}{|c|}{ RA patients $(n=140)$} & \multicolumn{5}{|c|}{ Controls $(n=138)$} & \multirow[b]{2}{*}{$p$} \\
\hline & $\mathrm{n}$ & $\%$ & Mean \pm SD & Median & Min.-Max. & $\mathrm{n}$ & $\%$ & Mean \pm SD & Median & Min.-Max. & \\
\hline \multicolumn{12}{|l|}{ Gender } \\
\hline Female $(\mathrm{n}=216)$ & 120 & 85.7 & & & & 96 & 69.6 & & & & $0.001^{*}$ \\
\hline Male $(n=62)$ & 20 & 14.3 & & & & 42 & 30.4 & & & & \\
\hline Age & & & $51.18 \pm 9.73$ & 51 & $23-76$ & & & $46.08 \pm 16.88$ & 50.5 & $19-65$ & $0.231 \neq$ \\
\hline Duration of disease $(n=127)$ & & & $11.12 \pm 8.87$ & 9 & $1-46$ & & & & & & \\
\hline $\mathrm{RF}^{+} \S$ & 56 & 53.8 & & & & & & & & & \\
\hline $\mathrm{RF}-\S$ & 48 & 46.2 & & & & & & & & & \\
\hline Anti-CCP+\$ & 4 & 21.1 & & & & & & & & & \\
\hline Anti-CCP-§ & 15 & 78.9 & & & & & & & & & \\
\hline $\operatorname{DAS}_{28}^{\S}(\mathrm{n}=120)$ & & & $3.7 \pm 1.5$ & 3.5 & $0.5-7.1$ & & & & & & \\
\hline $\operatorname{ESR}(\mathrm{mm} / \mathrm{h})(\mathrm{n}=139)$ & & & $30.7 \pm 22.32$ & 25 & $2-120$ & & & & & & \\
\hline $\mathrm{CRP}(\mu \mathrm{g} / \mathrm{ml})(\mathrm{n}=140)$ & & & $10.4 \pm 14.6$ & 4.5 & $0.7-103$ & & & & & & \\
\hline Number of swollen joints $(n=130)$ & & & $1.5 \pm 2.8$ & 0 & $0-21$ & & & & & & \\
\hline Number of tender joints $(n=131)$ & & & $7.6 \pm 8.7$ & 3 & $0-28$ & & & & & & \\
\hline
\end{tabular}


treatment program based upon the recommendations of the Turkish League Against Rheumatism (TLAR). ${ }^{28}$ The patients and controls were matched according to age and ethnic origin, and no consanguinity was present among the two groups. Clinical data, such as age, gender, disease duration, immunoglobulin $\mathrm{M}$ (IgM) rheumatoid factor (RF) levels, IgG antibodies to cyclic citrulinated peptides (anti-CCP), C-reactive protein (CRP), erythrocyte sedimentation rate (ESR), tender joint count, swollen joint count, and Disease Activity Score 28-joint assessment (DAS28), ${ }^{29}$ was provided by the clinicians. Disease activity was determined on the basis of the following defined parameters: the number of tender and swollen joints, DAS28 evaluation, CRP, and ESR.

\section{Biochemical analysis}

Blood samples were drawn from all of the subjects after an overnight fast and were then separated immediately and stored at $-20{ }^{\circ} \mathrm{C}$. The CRP and the IgM RF levels were measured via laser nephelometry, and the RF was considered to be positive when it was above $15.9 \mathrm{IU} / \mathrm{ml}$. In addition, the anti-CCP levels were detected using an enzyme-linked immunosorbent assay (ELISA) test, and a concentration $>5 \mathrm{RU} / \mathrm{ml}$ was considered to be positive.

\section{Genotyping}

Genomic DNA was extracted from the peripheral blood lymphocytes using an AbsoGene ${ }^{\circledR}$ DNA isolation kit (RTA Laboratuvarları Biyolojik Ürünler Ilaç ve Makine San. Tic. A.S., Gebze, Kocaeli, Turkey) according to the manufacturer's instructions, and the DNA samples were frozen and stored at minus $20{ }^{\circ} \mathrm{C}$ until analyzed. The rs7574865 and rs10181656 SNPs in the third intron of the STAT4 gene were amplified by polymerase chain reaction (PCR), and the 5'- TTATGGAAAATTACATGAGTGTG-3' and 5'- GCAAATCTTTGTAAAAAGTCAA-3' primers were used to generate a region of $156 \mathrm{bp}$ in the STAT4 gene that could be used in the subsequent genotyping reactions of the rs7574865 polymorphism. Furthermore, the pair of primers that were employed to generate a region of $157 \mathrm{bp}$ in the STAT4 gene that could be utilized for the subsequent genotyping reactions of the rs10181656 polymorphism were 5'- AGTTTTCAAAGTCTAACACTGTG -3' and 5'- GCTGCCATGTCGAGAGTA $-3{ }^{3}{ }^{30}$ The PCR amplifications of the related regions were carried out in $50 \mu \mathrm{l}$ volumes of reaction mixtures containing $75 \mathrm{mM}$ Tris-hydrochloride (Tris- $\mathrm{HCl})(\mathrm{pH} 8.8)$, $20 \mathrm{mM}$ ammonium sulfate [(NH4)2SO4], 0.01\% polyoxyethylenesorbitan monolaurate (Tween-20), $1.5 \mathrm{mM}$ magnesium chloride $(\mathrm{MgCl} 2), 200 \mu \mathrm{M}$ of each deoxyribonucleotide triphosphates (dNTP), $20 \mathrm{pmol} / \mathrm{L}$ of each set of specific primers (metabion international AG, Martinsried, Germany), 1 unit Taq DNA polymerase (MBI Fermentas, Amherst, NY, USA), and $0.2-0.5 \mu \mathrm{g}$ of the DNA sample. After the DNA was denatured at $94{ }^{\circ} \mathrm{C}$ for five minutes, the reaction mixture was subjected to 30 cycles of denaturation at $94{ }^{\circ} \mathrm{C}$ for 30 seconds, annealing at $55{ }^{\circ} \mathrm{C}$ for 60 seconds, and extension at $72{ }^{\circ} \mathrm{C}$ for 60 seconds. This was followed by five minutes of extension at $72{ }^{\circ} \mathrm{C}$. The reactions were performed in a thermal cycler (Perkin Elmer, Waltham, MA, USA), and the amplified products were run in a $2 \%$ agarose gel electrophoresis stained with ethidium bromide. The gels were then visualized and photographed using an ultraviolet light transilluminator.

The genotyping of the STAT4 rs7574865 and rs10181656 SNPs was performed using a polymerase chain reaction-restriction fragment length polymorphism (PCR-RFLP) analysis.

To determine the presence of the rs7574865 polymorphism, 156bp PCR products were digested with the Msel (T'TAA) (MBI Fermentas, Amherst, NY, USA) restriction enzyme for three hours at $37{ }^{\circ} \mathrm{C}$ and then run in a $3 \%$ agarose gel electrophoresis stained with ethidium bromide. The Msel digestion cleaved the 156 bp PCR products into two fragments of $94 \mathrm{bp}$ and $62 \mathrm{bp}$ when the $\mathrm{T}$ allele was present, whereas the $\mathrm{G}$ allele was not digested and displayed only the 156 bp band.

To determine the presence of the rs 10181656 polymorphism, $157 \mathrm{bp}$ PCR products were digested with the Ddel (C'TNAG) (MBI Fermentas, Amherst, NY, USA) restriction enzyme for the same amount of time at the same temperature and also run in a 3\% agarose gel electrophoresis stained with ethidium bromide. The Ddel digestion cleaved the $157 \mathrm{bp}$ PCR products into two fragments of $102 \mathrm{bp}$ and $55 \mathrm{bp}$ when the $\mathrm{C}$ allele was present, whereas the $\mathrm{G}$ allele was not digested and displayed only the 157 bp band. 


\begin{tabular}{|c|c|c|c|c|c|c|}
\hline & \multirow[t]{2}{*}{ Allele } & \multicolumn{2}{|c|}{ RA patients } & \multicolumn{2}{|c|}{ Controls } & \multirow[b]{2}{*}{$p^{*}$} \\
\hline & & $\mathrm{n}$ & $\%$ & $\mathrm{n}$ & $\%$ & \\
\hline STAT4 & G & 195 & 0.70 & 197 & 0.71 & \multirow{2}{*}{0.654} \\
\hline rs7574865 & $\mathrm{T}$ & 85 & 0.30 & 79 & 0.29 & \\
\hline STAT4 & G & 192 & 0.69 & 195 & 0.71 & \multirow{2}{*}{0.594} \\
\hline rs10181656 & C & 88 & 0.31 & 81 & 0.29 & \\
\hline
\end{tabular}

Analysis of the relationship between the two STAT4 polymorphisms and the clinical and laboratory data of the RA patients.

Thereafter, we studied the relationship between the genotype distribution of the two polymorphisms and the clinical and laboratory data in the RA group. The stratification analysis was undertaken to account for age, disease duration, and the number of swollen and tender joints in the patients as well as the results of the laboratory investigations involving CRP, ESR, the RF values, and disease activity evaluations (DAS28).

\section{Statistical analysis}

Continuous data was summarized as mean \pm standard deviation (SD) and median (minimummaximum), whereas frequencies and percentages were used for categorical data. The Mann-Whitney $\mathrm{U}$ test was used to compare the ages of the RA patients and controls, and Pearson's chi-square test was performed to assess the allele, genotype, and haplotype frequencies and calculate the HardyWeinberg equilibrium. In addition, the KruskalWallis test or one-way analysis of variance (ANOVA) was used to compare the two groups, where applicable. Haplotype construction was performed using a partition-ligation-combination-subdivision EM algorithm, ${ }^{31}$ and descriptive statistics and group comparisons were performed using the IBM SPSS Statistics v.20.0 software program (IBM Corporation, Armonk, NY, USA). Furthermore, allele, genotype, and haplotype frequencies, the Hardy-Weinberg equilibrium, linkage disequilibrium, and haplotype construction were calculated using the SHEsis ${ }^{32}$ software. A $p$ value of $<0.05$ was considered to be significant.

\section{RESULTS}

\section{Clinical phenotypes of the study subjects}

There were no significant differences between the RA patients and controls with respect to age $(\mathrm{p}=0.231)$. The mean age of the RA patients was $51.18 \pm 9.73$ (median 51 years old; range 23-76), whereas it was $46.08 \pm 16.88$ for the controls (median 50.5 years old; range 19-65). Unfortunately, the laboratory data was not available for some cases, but 127 out of 140 RA patients had disease duration records, and the mean was $11.12 \pm 8.87$ years (median 9 years; range $1-46$ ). Moreover, 104 of the RA patients had RF records,

Table 3. Genotype distributions of the two single nucleotide polymorphisms in the signal transducer and activator of transcription 4 gene in the patient and control groups

\begin{tabular}{|c|c|c|c|c|c|c|}
\hline & \multirow[t]{2}{*}{ Genotype } & \multicolumn{2}{|c|}{ RA patients } & \multicolumn{2}{|c|}{ Controls } & \multirow[b]{2}{*}{$p^{*}$} \\
\hline & & $\mathrm{n}$ & $\%$ & $\mathrm{n}$ & $\%$ & \\
\hline STAT4 & TG & 63 & 0.45 & 55 & 0.40 & \multirow{3}{*}{0.686} \\
\hline \multirow[t]{2}{*}{ rs7574865 } & TT & 11 & 0.08 & 12 & 0.09 & \\
\hline & GG & 66 & 0.47 & 71 & 0.51 & \\
\hline STAT4 & GC & 66 & 0.47 & 55 & 0.40 & \multirow{3}{*}{0.467} \\
\hline \multirow{2}{*}{ rs10181656 } & GG & 63 & 0.45 & 70 & 0.51 & \\
\hline & $\mathrm{CC}$ & 11 & 0.08 & 13 & 0.09 & \\
\hline
\end{tabular}


and 56 (53.8\%) had tested positive while 48 (46.2\%) were negative. Four (21.1\%) of the RA patients were positive for anti-CCP, but 15 (78.9\%) tested negative. Furthermore, 120 of the RA patients had a DAS28 value, and the mean was $3.7 \pm 1.5$ (median DAS28 3.5; range 0.5-7.1). We also found ESR results for 139 of the RA patients, and the mean was $30.7 \pm 22.32$ (median 25; range 2-120). Additionally, the mean CRP was $10.4 \pm 14.46$ (median 4.5 ; range $0.7-103)$. There were also 130 patients with swollen joints with a mean of $1.5 \pm 2.8$ (median 0; range 0-21) and 131 had tender joints with a mean of $7.6 \pm 8.7$ (median 3; range 0-28) (Table 1).

\section{An association study involving the RA patients and controls}

The STAT4 rs7574865 and rs10181656 polymorphisms were successfully genotyped in all of the subjects, and both the patient and control groups were in equilibrium ( $p=0.773$ and $p=0.447$; $p=0.647$ and $p=0.267$, respectively). The genotype distributions and allele frequencies of the STAT4 rs7574865 and rs10181656 polymorphisms were compared between the RA patients and the control group, and the allele frequencies and genotype distributions of all of the analyzed samples of the STAT4 rs7574865 and rs10181656 polymorphisms from both groups are displayed in Table 2 and 3, respectively. Regarding the two polymorphisms, there were no significant differences between the groups with respect to the allele frequencies $(p=0.654$ and $p=0.594$, respectively) and genotype distributions $(p=0.654$ and $\mathrm{p}=0.594$, respectively).

Relationship between the two STAT4 polymorphisms and the clinical and laboratory data of the RA patients

None of the clinical features or disease activity parameters showed any correlation with the rs7574865 and rs10181656 genotype distribution of the STAT4 gene in the RA patients (Table 4a, b).

\section{STAT4 haplotype analysis}

The two SNPs were in complete linkage disequilibrium, which was consistent with the findings in previous studies ( $\left.D^{\prime}=1, r 2=0.96\right) .{ }^{10,12-21}$ The haplotype block consisted of the rs7574865 and rs10181656 SNPs, and frequencies of less than 0.001 in both the RA and controls were

Table 4a. The relationship between signal transducer and activator of transcription 4 rs7574865, rs10181656 genotypes and the clinical and laboratory findings of the rheumatoid arthritis patients

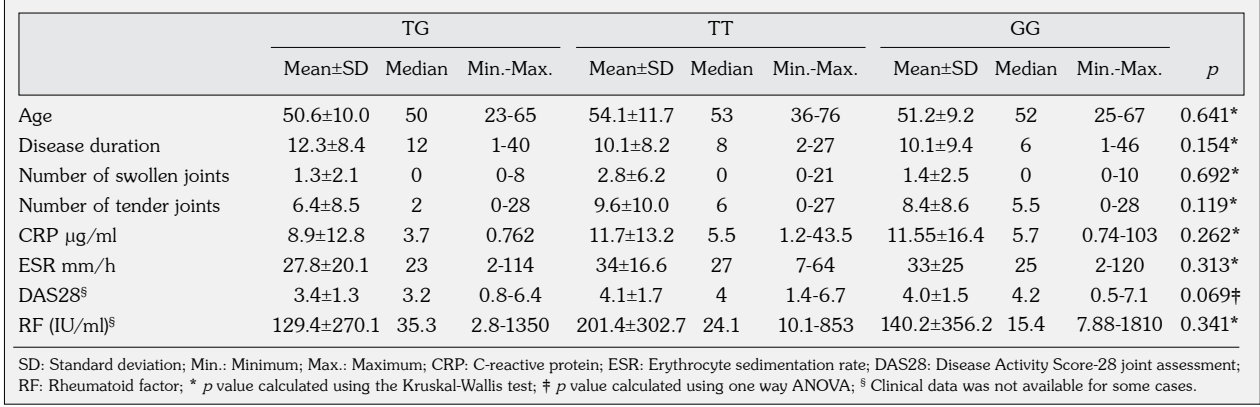

Table 4b. Continued

\begin{tabular}{|c|c|c|c|c|c|c|c|c|c|}
\hline & \multicolumn{3}{|c|}{ GC } & \multicolumn{3}{|c|}{ GG } & \multicolumn{3}{|c|}{$\mathrm{CC}$} \\
\hline & Mean \pm SD & Median & Min.-Max. & Mean \pm SD & Median & Min.-Max. & Mean \pm SD & Median & Min.-Max. \\
\hline Age & $50.4 \pm 10.0$ & 50 & $23-65$ & $51.4 \pm 9.3$ & 52 & $25-67$ & $54.1 \pm 11.7$ & 53 & $36-76$ \\
\hline Disease duration & $12.1 \pm 8.2$ & 11 & $1-40$ & $10.3 \pm 9.7$ & 6 & $1-46$ & $10.1 \pm 8.2$ & 8 & $2-27$ \\
\hline Number of swollen joints & $1.3 \pm 2.0$ & 0 & $0-8$ & $1.4 \pm 2.5$ & 0 & $0-10$ & $2.8 \pm 6.2$ & 0 & $0-21$ \\
\hline Number of tender joints & $6.9 \pm 8.9$ & 2 & $0-28$ & $8.1 \pm 8.3$ & 5 & $0-28$ & 9.610 .0 & 6 & $0-27$ \\
\hline $\mathrm{CRP} \mu \mathrm{g} / \mathrm{ml}$ & $8.7 \pm 12.5$ & 3.7 & $0.7-62$ & $11.9 \pm 16.7$ & 5.7 & $0.74-103$ & $2.8 \pm 6.2$ & 0 & $0-21$ \\
\hline $\mathrm{ESR} \mathrm{mm} / \mathrm{h}$ & $28.0 \pm 19.7$ & 24.5 & $2-114$ & $33.1 \pm 25.5$ & 24.5 & $2-120$ & $34 \pm 16.6$ & 27 & $7-64$ \\
\hline DAS28 $8^{\varsigma}$ & $3.4 \pm 1.3$ & 3.2 & $0.8-6.4$ & $4.0 \pm 1.5$ & 4.2 & $0.5-7.1$ & $4.1 \pm 1.7$ & 4.0 & $1.4-6.7$ \\
\hline $\mathrm{RF}(\mathrm{IU} / \mathrm{ml})^{\S}$ & $127 \pm 268$ & 32.7 & $2.8-1350$ & $143.3 \pm 359.7$ & 16.3 & $8.2-1810$ & $201.4 \pm 302.7$ & 24.1 & $10.1-583$ \\
\hline
\end{tabular}


Table 5. The frequencies of the signal transducer and activator of transcription 4 haplotypes in the patient and control groups

\begin{tabular}{|c|c|c|c|c|c|}
\hline \multirow[t]{2}{*}{ Haplotype } & \multicolumn{2}{|c|}{ RA patients } & \multicolumn{2}{|c|}{ Controls } & \multirow[b]{2}{*}{$p^{*}$} \\
\hline & $\mathrm{n}$ & $\%$ & $\mathrm{n}$ & $\%$ & \\
\hline GC & 3 & 0.010 & 2 & 0.007 & \\
\hline GG & 192 & 0.686 & 195 & 0.707 & 0.813 \\
\hline TC & 85 & 0.304 & 79 & 0.286 & \\
\hline
\end{tabular}

Haplotype block consists of the rs7574865 and rs10181656 single nucleotide polymorphisms; Frequencies of less than 0.001 in both rheumatoid arthritis (RA) and controls were dropped; * $p$ value calculated using Pearson's chi-square test.

dropped. Three (1\%) of the RA patients had the GC haplotype, 192 (68.6\%) had the GG haplotype, and 85 had (30.4\%) the TC haplotype. In addition, two $(0.7 \%)$ of the healthy controls had the GC haplotype, 195 (70.7\%) had the GG haplotype, and 79 (28.6\%) had the TC haplotype. However, we found no significant differences between the RA patients and controls $(\mathrm{p}=0.813)$ (Table 5).

\section{DISCUSSION}

In our previous study regarding the current advances in the genetic basis of RA, we observed that many studies had investigated the association between RA and the STAT4 gene, and these had confirmed the results across two major ethnic groups. ${ }^{10,12,13,17,33}$ After we published those findings, we ran across some conflicting results that led us to the ethnic-based differential association between specific STAT4 markers and RA susceptibility. Thus, we believed there was a need for additional research into the genetics of this gene in the Turkish population.

In this study, we investigated the association betwen the candidate gene STAT4 and RA in a Turkish population for the first time. Our primary finding was that the two SNPs that we examined in the third intron of the STAT4 gene were not associated with a susceptibility to RA in Turkish patients. Furthermore, our results suggested that none of the clinical features and disease activity parameters showed any correlation with the rs7574865 and rs10181656 genotype distribution of the STAT4 gene in RA patients. This replication failure in a Turkish population supports the data of the aforementioned studies that focused on the Southwestern Chinese Han and African-American populations. ${ }^{10,22,23}$ It is possible that this observed incongruence between the different populations could stem from differences in the genetic background of the study groups, small sample sizes, or an inadequate definition of the phenotypes.

Our study had some limitations. First, the sample size was small, which may have limited the statistical power to detect any existing association. Furthermore, we examined only two polymorphisms because of their relatively high frequency, and the laboratory infrastucture only enabled us to design a study using the PCR-RFLP technique. However, additional polymorphisms exist in the STAT4 gene that might contribute to the susceptibility or activity of RA. Although these disadvantages existed in the formation of the study protocol, since this was the first study in the literature conducted to determine whether the STAT4 rs7574865 and rs10181656 gene polymorphisms were a genetic marker of susceptibility to or the activity of RA in a Turkish population, our findings were still valuable.

\section{Conclusion}

The obtained data from this study demonstrates that the rs7574865 and rs10181656 polymorphisms in the STAT4 gene are not associated with susceptibility to RA in Turkish population. Furthermore, our findings along with those that involved the Southwestern Chinese Han and African-American populations, indicate the need to replicate this study; however, in the future, different ethnic populations with larger sample sizes should be used. In addition, subsequent research is also needed to detect the eventual functional significance of the polymorphisms in this study as well as any possible links with other polymorphisms possessing the known functional effect.

\section{Acknowledgements}

We thank Prof. Ömür Ataoglu MD. for generously opening his laboratory infrastructure to us for this study.

\section{Declaration of conflicting interests}

The authors declared no conflicts of interest with respect to the authorship and/or publication of this article.

\section{Funding}

This work was founded by the Turkish League Against Rheumatism. 


\section{REFERENCES}

1. Firestein GS. Evolving concepts of rheumatoid arthritis. Nature 2003;423:356-61.

2. van der Helm-van Mil AH, Wesoly JZ, Huizinga TW. Understanding the genetic contribution to rheumatoid arthritis. Curr Opin Rheumatol 2005;17:299-304.

3. Newton JL, Harney SM, Wordsworth BP, Brown MA. A review of the $\mathrm{MHC}$ genetics of rheumatoid arthritis. Genes Immun 2004;5:151-7.

4. Bowes J, Barton A. Recent advances in the genetics of RA susceptibility. Rheumatology (Oxford) 2008;47:399402.

5. Begovich AB, Carlton VE, Honigberg LA, Schrodi SJ, Chokkalingam AP, Alexander $\mathrm{HC}$, et al. A missense single-nucleotide polymorphism in a gene encoding a protein tyrosine phosphatase (PTPN22) is associated with rheumatoid arthritis. Am J Hum Genet 2004;75:330-7.

6. Orozco G, Sánchez E, González-Gay MA, López-Nevot MA, Torres B, Cáliz R, et al. Association of a functional single-nucleotide polymorphism of PTPN22, encoding lymphoid protein phosphatase, with rheumatoid arthritis and systemic lupus erythematosus. Arthritis Rheum 2005;52:219-24.

7. Lee YH, Rho YH, Choi SJ, Ji JD, Song GG, Nath SK, et al. The PTPN22 C1858T functional polymorphism and autoimmune diseases--a meta-analysis. Rheumatology (Oxford) 2007;46:49-56.

8. Wellcome Trust Case Control Consortium. Genomewide association study of 14,000 cases of seven common diseases and 3,000 shared controls. Nature 2007;447:661-78.

9. Plenge RM, Seielstad M, Padyukov L, Lee AT, Remmers EF, Ding B, et al. TRAF1-C5 as a risk locus for rheumatoid arthritis--a genomewide study. N Engl J Med 2007;357:1199-209.

10. Tong G, Zhang X, Tong W, Liu Y. Association between polymorphism in STAT4 gene and risk of rheumatoid arthritis: a meta-analysis. Hum Immunol 2013;74:586-92.

11. Amos CI, Chen WV, Lee A, Li W, Kern M, Lundsten R, et al. High-density SNP analysis of 642 Caucasian families with rheumatoid arthritis identifies two new linkage regions on 11 p12 and 2q33. Genes Immun 2006;7:277-86.

12. Remmers EF, Plenge RM, Lee AT, Graham RR, Hom G, Behrens TW, et al. STAT4 and the risk of rheumatoid arthritis and systemic lupus erythematosus. N Engl J Med 2007;357:977-86.

13. Lee HS, Remmers EF, Le JM, Kastner DL, Bae SC, Gregersen PK. Association of STAT4 with rheumatoid arthritis in the Korean population. Mol Med 2007;13:455-60.

14. Orozco G, Alizadeh BZ, Delgado-Vega AM, GonzálezGay MA, Balsa A, Pascual-Salcedo D, et al. Association of STAT4 with rheumatoid arthritis: a replication study in three European populations. Arthritis Rheum 2008;58:1974-80.
15. Palomino-Morales RJ, Rojas-Villarraga A, González CI, Ramírez G, Anaya JM, Martín J. STAT4 but not TRAF1/C5 variants influence the risk of developing rheumatoid arthritis and systemic lupus erythematosus in Colombians. Genes Immun 2008;9:379-82.

16. Zervou MI, Sidiropoulos P, Petraki E, Vazgiourakis V, Krasoudaki E, Raptopoulou A, et al. Association of a TRAF1 and a STAT4 gene polymorphism with increased risk for rheumatoid arthritis in a genetically homogeneous population. Hum Immunol 2008;69:567-71.

17. Kobayashi S, Ikari K, Kaneko H, Kochi Y, Yamamoto $\mathrm{K}$, Shimane $\mathrm{K}$, et al. Association of STAT4 with susceptibility to rheumatoid arthritis and systemic lupus erythematosus in the Japanese population. Arthritis Rheum 2008;58:1940-6.

18. Mohamed RH, Pasha HF, El-Shahawy EE. Influence of TRAF1/C5 and STAT4 genes polymorphisms on susceptibility and severity of rheumatoid arthritis in Egyptian population. Cell Immunol 2012;273:67-72.

19. Liang YL, Wu H, Li PQ, Xie XD, Shen X, Yang XQ, et al. Signal transducer and activator of transcription 4 gene polymorphisms associated with rheumatoid arthritis in Northwestern Chinese Han population. Life Sci 2011;89:171-5.

20. Zhao Y, Liu X, Liu X, Su Y, Li Y, Zhang X, et al. Association of STAT4 gene polymorphism with increased susceptibility of rheumatoid arthritis in a northern Chinese Han subpopulation. Int J Rheum Dis 2013;16:178-84.

21. Shen L, Liu R, Zhang H, Huang Y, Sun R, Tang P. Replication study of STAT4 rs7574865 G/T polymorphism and risk of rheumatoid arthritis in a Chinese population. Gene 2013;526:259-64.

22. Li H, Zou Q, Xie Z, Liu Y, Zhong B, Yang S, et al. A haplotype in STAT4 gene associated with rheumatoid arthritis in Caucasians is not associated in the Han Chinese population, but with the presence of rheumatoid factor. Rheumatology (Oxford) 2009;48:1363-8.

23. Kelley JM, Hughes LB, Malik A, Danila MI, Edberg Y, Alarcón GS, et al. Genetic variants of STAT4 associated with rheumatoid arthritis in persons of Asian and European ancestry do not replicate in African Americans. Ann Rheum Dis 2010;69:625-6.

24. Frucht DM, Aringer M, Galon J, Danning C, Brown M, Fan S, et al. Stat4 is expressed in activated peripheral blood monocytes, dendritic cells, and macrophages at sites of Th1-mediated inflammation. $\mathrm{J}$ Immunol 2000;164:4659-64.

25. Watford WT, Hissong BD, Bream JH, Kanno Y, Muul L, O'Shea JJ. Signaling by IL-12 and IL-23 and the immunoregulatory roles of STAT4. Immunol Rev 2004;202:139-56.

26. McInnes IB, Schett G. Cytokines in the pathogenesis of rheumatoid arthritis. Nat Rev Immunol 2007;7:429-42. 
27. Arnett FC, Edworthy SM, Bloch DA, McShane DJ, Fries JF, Cooper NS, et al. The American Rheumatism Association 1987 revised criteria for the classification of rheumatoid arthritis. Arthritis Rheum 1988;31:315-24.

28. Ataman S, Borman P, Evcik D, Aydog E, Ayhan F, Yildizlar D, et al. Management of rheumatoid arthritis: consensus recommendations from the Turkish League Against Rheumatism. Turk J Rheumatol 2011;26:273-94.

29. Prevoo ML, van 't Hof MA, Kuper $\mathrm{HH}$, van Leeuwen MA, van de Putte LB, van Riel PL. Modified disease activity scores that include twenty-eight-joint counts. Development and validation in a prospective longitudinal study of patients with rheumatoid arthritis. Arthritis Rheum 1995;38:44-8.
30. Glas J, Seiderer J, Nagy M, Fries C, Beigel F, Weidinger $\mathrm{M}$, et al. Evidence for STAT4 as a common autoimmune gene: rs7574865 is associated with colonic Crohn's disease and early disease onset. PLoS One 2010;5:e10373.

31. Li Z, Zhang Z, He Z, Tang W, Li T, Zeng Z, et al. A partition-ligation-combination-subdivision EM algorithm for haplotype inference with multiallelic markers: update of the SHEsis (http://analysis.bio-x.cn). Cell Res 2009;19:519-23.

32. Shi YY, He L. SHEsis, a powerful software platform for analyses of linkage disequilibrium, haplotype construction, and genetic association at polymorphism loci. Cell Res 2005;15:97-8.

33. Yüksel-Konuk B, Baltacı V. Current advances in the genetic basis of rheumatoid arthritis.Turk $\mathrm{J}$ Rheumatol 2009;24:218-21. 